\title{
Screening of the use of benzodiazepines during COVID-19 pandemic in the general population
}

\author{
Viktor Isjanovski $^{1^{*}}$, Milijana Kacarska ${ }^{2}$ \\ ${ }^{1}$ Psychiatric hospital "Skopje", Skupi 20 No. 56, 1000 Skopje, RN Macedonia \\ ${ }^{2}$ PZU Vita Medika, Vanco Kitanov No. 19, 2400 Strumica, RN Macedonia
}

Received: April 2021; Accepted: May 2021

\begin{abstract}
Benzodiazepines have been commonly prescribed for the treatment of anxiety and insomnia in the last few decades. There has been a rising concern regarding safety of benzodiazepines due to overdose related deaths, addictions and cognitive side effects. COVID-19 pandemic is expected to cause a mental health crisis. Several studies have shown an increase in anxiety and insomnia. The prescriptions of benzodiazepines could increase due to increase in anxiety and insomnia. The pandemic calls for a rapid adaptation of conventional medical practices to meet the evolving needs of such vulnerable patients. COVID-19 patients may frequently require treatment with psychotropic medications. This pandemic is leading to additional health problems such as stress, anxiety, depressive symptoms, insomnia, denial, anger and fear, globally.

The COVID-19 pandemic is a challenge to humanity. It is not only a health crisis but also a social crisis. The life is unlikely to be the same after we come out of the pandemic. There will be changes at the level of individuals, families, communities, states, nations, international relationships, and the way all of us will deal with a range of human and environmental situations. Disasters are always associated with increased rates of emotional health needs from distress to specific disorders, such as posttraumatic stress disorder. Past experiences have shown psychosocial interventions, ranging from self-care, psychological first aid, counseling, social support and formal psychiatric care can minimize the emotional health impact of disasters. These activities can be initiated by individuals and professionals.
\end{abstract}

Keywords: coronavirus, COVID-19, mental health, benzodiazepines

\section{Introduction}

The corona virus pandemic is a global health emergency calling for a rapid adaptation of conventional clinical practices in many medical areas, including psychiatry. Corona virus disease (COVID-19) is a systemic infection potentially targeting multiple organs and functions. Interstitial pneumonia is the landmark feature of this condition, leading to severe respiratory distress requiring intensive life support in about one out of twenty symptomatic cases (Grasselli et al., 2020; Wu and McGoogan, 2020). Old age and preexisting medical

\footnotetext{
* viktorisjanovski@yahoo.com
}

comorbidities are associated with increased severity and mortality (Yang et al., 2020).

This epidemic leads to additional health problems such as: stress, anxiety, depressive symptoms, insomnia, denial, anger and fear, globally. Collective problems affect day-to-day behavior, cost-effectiveness and preventive decision-making strategies by health organizations and medical centers, which may weaken COVID-19 control strategies and lead to greater morbidity and global mental health needs (Torales et al., 2020).

Benzodiazepines have been around since the 1960s and they have been one of the most commonly prescribed medications worldwide. Over years, there has been a 
rising concern of the risk of overdose-related deaths, addiction, and long-term cognitive concerns with benzodiazepines. As per the Centers for Disease Control and Prevention (CDC), there were 67367 deaths in the United States due to overdose in 2018. Synthetic opiates were the main drugs involved in deaths. As per the National Institute on Drug Abuse (NIDA), benzodiazepines were involved in more than $30 \%$ of the opiates-related overdose-related deaths (CDC, 2020; NIDA, 2020; Torales et al., 2020).

Benzodiazepines are used to treat anxiety, sleep disorders and other conditions. Oral overdose with benzodiazepines, without co-ingestion, rarely results in significant morbidity or mortality. However, patients often do not take them as prescribed, use them in combination with other drugs or substances, or both. The U.S. Food and Drug Administration recently requested an update to the benzodiazepine warning to include the risks of abuse, misuse, addiction, physical dependence, and withdrawal reactions. Prescription of benzodiazepines has increased dramatically over the past decade and during the COVID19 pandemic. According to research, psychiatrists who prescribe benzodiazepines are at a sustainable level (29.6\% vs. $30.2 \%$ now), but primary care physicians have increased (3.6\% vs. 7.5\%) (Agrawal, 2020; Agarwal and Landon, 2019). Primary health care prescribes about half of all benzodiazepine prescriptions. This growing pattern of benzodiazepine prescriptions is very worrying amid the COVID-19 pandemic.

The COVID-19 pandemic could cause a mental health crisis. Studies have shown an increase in anxiety and insomnia in health care providers, as well as in the general (Agarwal and Landon, 2008; Lai et al., 2020; Pappa et al., 2020). According to a survey conducted by the American Psychiatric Association in March 2020, $48 \%$ of the general population reported anxiety, $36 \%$ reported that the pandemic was severely affecting their mental health, and 19\% reported insomnia. Pappa et al. (2020), during the pandemic showed a prevalence of $23.2 \%$ anxiety and $22.8 \%$ depression in health workers. In one study of health care providers treating patients with COVID-19 in China, 50.4\% reported depression, $44.6 \%$ anxiety, 34\% insomnia, and $71.5 \%$ distress (Lai et al., 2020). This increase in anxiety, insomnia and depression is alarming in both the general population and health professionals. Hence, it can be predicted that there will be an increase in the use of prescription benzodiazepines.

Social isolation and lack of ready access to support is another risk factor (Baldessarini, 2019). Pandemic social isolation measures can have a ripple effect on mental health as the support network may be disrupted for some people. There is a lot of fear of illness, death, finances, housing, unemployment, childcare due to a pandemic. The longer this pandemic lasts, the worse it will be for mental health. Stress can activate the hypothalamic-pituitary axis which really increases cortisol. Cortisol is a steroid hormone that plays a role in the stress response and immunity along with other functions. Chronic stress can increase inflammatory conditions in the body, reduce immunity (Wolf et al., 2008). During this time of pandemic when we have no treatment for COVID-19, we need immunity to fight this infection.

Insomnia can be caused by acute stress and over time can become chronic. People who have a high sleep response are more prone to stress insomnia. Sleep reactivity is a trait that some people may have and is also associated with a risk of depression and anxiety (Kalmbach et al., 2018). There has been an increase in insomnia due to the pandemic and can be explained by cognitive impairments, survivors that some people may have at bedtime. Bed rest can increase anxiety and link sleep time to anxiety, so relaxation techniques, such as progressive muscle relaxation, can help us relax before bed and reduce sleep latency. A study by Palagini et al. (2018), of subjects with insomnia found that low elasticity was associated with a high sleep response associated with stress, emotional dysregulation, and hyperarousal.

Therefore, the main target of this research paper is investigation on the use of benzodiazepines during the COVID-19 pandemic in the general population.

\section{Materials and methods}

An analytical cross-sectional study was prepared in the period from 06.2020 to 12.2020. A questionnaire was used which was compiled and evaluated by the authors. 260 survey questionnaires were sent through Google forms. The response rate is $92 \%$ (240). The research was conducted in Strumica and Skopje.

The survey questionnaire consists of III parts. The first part consists of 6 demographic questions. The second part consists of the benzodiazepines taken and the third part the benzodiazepines taken in the last 6 months.

The respondents are persons over 18 years of age, who agreed to take part in the survey. In one part of the survey, questionnaire uses a Likert-type scale - a scale of attitudes, which consists of a series of statements, dedicated to different aspects of an attitude. It is given to the respondent with the task to express a degree of agreement or disagreement for each individual statement, as a rule on a five-point scale, from disagree at all, to agree completely. Each answer of the respondent is scored in the appropriate way and then, by adding the statements, the total score is obtained, which expresses the attitude of the respondent, to a certain extent positive or negative. With five answer options, we used this odd Likert scale question to gather information about a topic by including a neutral answer option for respondents to select if they don't wish to answer from the extreme choices. Standard statistical descriptive methods were used. Difference test, rates and central tendency (mean) were determined. 


\section{Results}

A total number of 240 participants participated in the research. The participants in the survey are $82.9 \%$ females and $17.1 \%$ males The percentage difference is statistically significant for $p<0.05(p=0.0000)$.

$29.2 \%$ of the participants are aged from 40 to 49 , followed by the age of $30-39(27.5 \%), 60$ to $69(17.4 \%)$ etc. The percentage difference is statistically significant between the ages of 40-49 versus other age groups for $p<0.05(p=0.0100)$.

$67.5 \%$ have higher education, Masters are 30 $(11.9 \%)$, Doctors of Science are $12(5 \%)$, and $30.4 \%$ have secondary education. The representation of higher education is significant compared to the others $(p=$ $0.0000)$.

More than half of the respondents are married $(58.3 \%)$, employed are $70.0 \%$, and retired are $14.6 \%$. Most live in the city $-91.0 \%$ (Table 1).

Table 1. Overview of the demographic characteristics of the study participants

\begin{tabular}{lcc}
\hline Gender & $\mathrm{N}=240$ & $\%$ \\
Male & 41 & 17.1 \\
Female & 199 & 82.9 \\
\hline Age & & \\
$<30$ & 22 & 9.2 \\
$30-39$ & 48 & 20.0 \\
$40-49$ & 70 & 29.2 \\
$50-59$ & 60 & 25.0 \\
$60-69$ & 32 & 13.3 \\
$>69$ & 8 & 3.3 \\
\hline Education level & & \\
Primary & 5 & 2.1 \\
High & 73 & 30.4 \\
Faculty & 120 & 50.0 \\
Masters & 30 & 11.9 \\
PhD & 12 & 5.0 \\
\hline Marital status & & \\
Married & 140 & 58.3 \\
extramarital & 16 & 6.7 \\
Divorced & 24 & 10.0 \\
Widow & 40 & 16.7 \\
Without a permanent & 20 & 8.3 \\
partner & & \\
\hline Employment status & & \\
Employee & 168 & 70.0 \\
Unemployed & 27 & 11.2 \\
Students & 10 & 4.2 \\
Pensioner & 35 & 14.6 \\
\hline Place of residence & & \\
Urban & 218 & 90.8 \\
Rural & 22 & 9.2 \\
\hline & & \\
\hline & & \\
\hline
\end{tabular}

To the first question "Have you ever been diagnosed with a psychiatric disorder", $33.3 \%$ of respondents answered yes compared to $66.7 \%$ who did not. Most of the $60 \%$ are neurotic and stress-related disorders and somatoform disorders (anxiety disorders) and 40\% are mood disorders (depression). Most of the respondents take alprazolam (Helex, Xanax) - 105 (43.75\%), Diazepam take $24.6 \%, 11.7 \%$ take Lexilium, while $8.7 \%$ take Demetrin, etc. The percentage difference compared to taking Alprazomal versus other types of drugs is statistically significant for $p<0.05(p=0.0000)$ (Table 2).

Benzodiazepines are mostly taken by the respondents due to anxiety $(57.5 \%)$, insomnia (40\%), tension $(37.5 \%)$, restlessness $(33.75 \%)$, fear $(28.3 \%)$, high blood pressure $(14.6 \%)$, etc. The percentage difference in taking Benzodiazepam due to anxiety versus the other modalities of the variables is statistically significant for $p<0.05$ $(p=0.0001)$ (Table 2).

Now most of the surveyed, $65 \%$ take benzodiazepines due to anxiety, $41.7 \%$ take them due to tension, $45.8 \%$ due to insomnia, $36.7 \%$ due to fear and $42.5 \%$ due to restlessness (Table 2).

According to the dynamics index, the rate of increase in benzodiazepine intake due to anxiety increased by $13 \%$, due to fear by $29.4 \%$, due to insomnia by $14.6 \%$, due to tension by $11.1 \%$, due to restlessness by 25.9 , etc. Generally, the use of benzodiazepines shows an increase rate of $20.9 \%$.

The drug does not help to $18(7.5 \%)$ of the respondents, moderately does not help to $28(11.7 \%)$, moderately good helps to $51(21.25 \%)$ of the respondents, helps well to $81(33.75 \%)$ and helps very well at 61 $(25.4 \%)$ of them. The percentage difference between those who are not helped by those who are helped by the drug $(19.2 \%$ vs. $80.8 \%)$ is statistically significant for $p<0.05(p=0.0000)$ on average, the respondents indicate the help of the drug with 6.8 (Table 2).

Most of the respondents take benzodiazepines on the advice of a psychiatrist (32.5\%), family doctor (26.25\%), self-initiated $(18.3 \%)$, and $14.2 \%$ take it on the advice of an internist. The percentage difference that benzodiazepines took on the advice of a psychiatrist and family doctor versus the other modalities is statistically significant for $p<0.05(p=0.0000)$ (Table 2).

$96.25 \%$ of respondents take prescription drugs, $75 \%$ of respondents tried to stop taking the drug, and $37.5 \%$ of respondents now need a higher dose of the drug.

$75 \%$ of the respondents take the drug daily, very often take $13.3 \%$ and very rarely $11.7 \%$. The percentage difference in relation to taking the drug daily versus the other modality of taking is statistically significant for $p<0.05(p=0.0000)$ (table 2).

The following answers refer to the drugs used in the last 6 months, these are views and claims. On the statement "Take a higher dose, otherwise I do not feel well" (P11), $70 \%$ of the respondents think that it is completely incorrect. The percentage difference in relation to the completely incorrect version of the other modality of the statement is statistically significant for 
Table 2. Overview of the answers (part II and III)

\begin{tabular}{|c|c|c|c|c|c|}
\hline question/Q & $\mathrm{N}=240$ & $\%$ & "question/Q & $\mathrm{N}=240$ & $\%$ \\
\hline Q1 & & & Q11 & & \\
\hline Yes & 80 & 33.3 & Completely incorrect & 168 & 70.0 \\
\hline No & 160 & 66.7 & Partially incorrect & 18 & 7.5 \\
\hline Q1a* & & & I am not sure & 24 & 10.0 \\
\hline F 32-33 & 32 & 40.0 & Partially true & 26 & 10.8 \\
\hline F 41-43 & 48 & 60.0 & Completely true & 4 & 1.7 \\
\hline Q2 & & & Q12 & & \\
\hline Helex & 67 & 27.9 & Completely incorrect & 145 & 60.4 \\
\hline Xanaks & 38 & 15.8 & Partially incorrect & 35 & 14.6 \\
\hline Diazepam & 59 & 24.6 & I am not sure & 16 & 6.7 \\
\hline Lexilium & 28 & 11.7 & Partially true & 35 & 14.6 \\
\hline Demetrin & 21 & 8.7 & Completely true & 9 & 3.75 \\
\hline Lorsilan, Lorazepam & 11 & 4.6 & Q13 & & \\
\hline Aclonil & 16 & 6.7 & Completely incorrect & 144 & 60.0 \\
\hline Q3 & & & Partially incorrect & 17 & 7.1 \\
\hline Anxiety & 138 & 57.5 & I am not sure & 16 & 6.7 \\
\hline Fear & 68 & 28.3 & Partially true & 31 & 12.9 \\
\hline Tension & 90 & 37.5 & Completely true & 32 & 13.3 \\
\hline Insomnia & 96 & 40.0 & Q14 & & \\
\hline Restlessness & 81 & 33.75 & Completely incorrect & 185 & 77.1 \\
\hline High pressure & 35 & 14.6 & Partially incorrect & 26 & 10.8 \\
\hline Other reasons & 33 & 13.75 & I am not sure & 11 & 4.6 \\
\hline $\mathrm{Q} 4$ & & & Partially true & 9 & 3.75 \\
\hline Anxiety & 156 & 65.0 & Completely true & 9 & 3.75 \\
\hline Habit & 18 & 7.5 & Q15 & & \\
\hline High pressure & 24 & 10.0 & Completely incorrect & 77 & 32.1 \\
\hline Insomnia & 110 & 45.8 & Partially incorrect & 24 & 5.7 \\
\hline Tension & 100 & 41.7 & I am not sure & 19 & 7.9 \\
\hline Fear & 88 & 36.7 & Partially true & 41 & 17.1 \\
\hline Restlessness & 102 & 42.5 & Completely true & & \\
\hline Other reasons & 36 & 15.0 & Q16 & & \\
\hline Q5 & & & Completely incorrect & 121 & 50.4 \\
\hline 1 & 9 & 3.75 & Partially incorrect & 24 & 10.0 \\
\hline 2 & 9 & 3.75 & I am not sure & 35 & 25.0 \\
\hline 3 & 11 & 4.6 & Partially true & 42 & 17.5 \\
\hline 4 & 17 & 7.1 & Completely true & 18 & 8.5 \\
\hline 5 & 29 & 12.1 & Q17 & & \\
\hline 6 & 22 & 9.2 & Completely incorrect & 44 & 18.3 \\
\hline 7 & 26 & 10.8 & Partially incorrect & 26 & 10.8 \\
\hline 8 & 55 & 23.0 & I am not sure & 11 & 4.6 \\
\hline 9 & 21 & 8.75 & Partially true & 150 & 62.5 \\
\hline 10 & 41 & 17.1 & Completely true & 9 & 3.75 \\
\hline Q6 & & & Q18 & & \\
\hline Family doctor & 63 & 26.25 & Completely incorrect & 73 & 30.4 \\
\hline Psychiatrist & 78 & 32.5 & Partially incorrect & 15 & 6.25 \\
\hline Internist & 34 & 14.2 & I am not sure & 12 & 5.0 \\
\hline Self-initiated & 44 & 18.3 & Partially true & 100 & 41.7 \\
\hline Pharmacist & 3 & 1.25 & Completely true & 40 & 16.7 \\
\hline Friend/relative & 10 & 4.2 & Q19 & & \\
\hline Another specialist & 8 & 3.3 & Completely incorrect & 120 & 50.0 \\
\hline Q7 & & & Partially incorrect & 20 & 8.3 \\
\hline Yes & 231 & 96.25 & I am not sure & 3 & 1.25 \\
\hline No & 9 & 3.75 & Partially true & 17 & 7.1 \\
\hline Q8 & & & Completely true & 80 & 33.3 \\
\hline Yes & 180 & 75.0 & Q20 & & \\
\hline No & 60 & 25.0 & Completely incorrect & 42 & 17.5 \\
\hline Q9 & & & Partially incorrect & 23 & 9.6 \\
\hline Yes & 90 & 37.5 & I am not sure & 5 & 2.1 \\
\hline No & 150 & 62.5 & Partially true & 131 & 54.6 \\
\hline Q10 & & & Completely true & 39 & 16.3 \\
\hline Daily, regular & 180 & 75.0 & *one do not give an answer & & \\
\hline very often & 32 & 13.3 & & & \\
\hline Very rare & 28 & 11.7 & & & \\
\hline
\end{tabular}


$p<0.05(p=0.0000)$ (Table 2). The average value of the answers among all respondents is 1.7 , which means that the statement of the respondents is between completely and partially incorrect.

To the statement "I get nervous if the drugs are not available to me" (P12), 60.4\% of the respondents think that it is completely incorrect. The percentage difference in relation to the completely incorrect version of the modality of the statement is statistically significant for $p<0.05(p=0.0000)$ (Table 2). The average value of the answers is 1.9 , which makes the claim of the respondents closer to partially incorrect.

On the statement "I was told to take a lower dose" (P13), 60\% of the respondents think that it is completely incorrect. The percentage difference in relation to the completely incorrect version of the other modality of the statement is statistically significant for $p<0.05$ $(p=0.0000)$ (Table 2). The average value of the Likert scale is 2.2 with which the claim of the respondents is partially incorrect.

On the statement "I take more drugs than prescribed" (P14), 77.1\% of the respondents consider it completely incorrect. The percentage difference compared to the completely incorrect version of the other modality of the statement is statistically significant for $p<0.05$ $(p=0.0000)$ (Table 2). The average value of the Likert scale is 1.5 with which the statement of all respondents is completely incorrect.

On the statement "I feel safe when I have medication with me" (Q15), the claim of the respondents is divided. Namely, $39.2 \%$ of the respondents think that it is completely incorrect, and $32.1 \%$ think that it is completely incorrect. The percentage difference in relation to completely incorrect and completely accurate version of the remaining modality of the statement is statistically significant for $p<0.05(p=0.0000)$ (Table 2). The average value of the answers is 3.1 , with which the statement of all the respondents is in the middle. There is an uncertainty in the answers.

On the statement "The effect of the drug is now weaker than at the beginning of taking" (P16), half of the respondents consider it to be completely incorrect $(50.4 \%)$. The percentage difference compared to the completely incorrect version of the remaining modality of the statement is statistically significant for $p<0.05$ $(p=0.0000)$ (Table 2). The average value of the Likert scale is 1.9 , with which the statement of all respondents is partially incorrect on average.

On the statement "I use drugs much faster now" (P17), half of the respondents think that it is partially true $(62.5 \%)$. The percentage difference versus the other modality of the statement is statistically significant for $p<0.05(p=0.0000)$ (Table 2). The average value of the answers is 3.1 with which claim the respondents are not sure.

To the statement "Immediately before taking the drug, I only think about it" (P18), $41.7 \%$ of the respondents think that it is partially true, and $30.4 \%$ completely incorrect. The percentage difference between the partially correct version and the modality of the statement is statistically significant for $p<0.05$ $(p=0.0000)$ (Table 2). The average value of the answers is 3.1 with which claim the respondents are not sure.

On the statement "I take the prescription before the scheduled check" (P19), 50\% of the respondents think that it is completely incorrect, and $33.3 \%$ completely correct. The percentage difference between the partially correct version and the modality of the statement is statistically significant for $p<0.05(p=0.0002)$ (Table 2). The average value of the answers is 2.7 , which claim the respondents are not sure about.

On the statement "I take a large amount of medication" (P20), 54.6\% of the respondents think that it is partially true. The percentage difference between the partially correct version and the modality of the statement is statistically significant for $p<0.05(p=0.0000)$ (Table 2 ). The average value of the answers is 3.7 , with which statement the respondents are partially correct.

\section{Discussion}

The last 12 months have been the most difficult and traumatic period for humanity. The world, as we all know, is upside down (Srinivasa, 2020). Social structures and their functioning are under pressure. The health of the population is a victim of the current pandemic. There is a fear of death and anxiety about the future among all individuals around the world (Brooks, 2020; Clopton, 2020, Davis, 2020; Hackethal, 2020; Sunita, 2020; Vijayakumar and Thara, 2020). Medical care services are stretched and healthcare workers are at risk of serious illness. The opinion is that the world will not be the same as it was before COVID-19.

There is much debate about the use of benzodiazepines in the medical community. Some support the use as a result of immediate benefits, some are not because of addiction, tolerance, risk of cognitive decline, etc. Conflict studies make it difficult to make the right decision when patients are seen in clinics and hospitals. There are limited resources for psychotherapy and this makes it difficult for primary care physicians to treat anxiety and insomnia. In our research, $1 / 4$ of the benzodiazepines were prescribed by a family doctor, $1 / 5$ of the respondents took the drug on their own initiative without a doctor's advice. $4 \%$ of respondents took the drug without a prescription, although benzodiazepines are available only on prescription. $33 \%$ of the respondents have a psychiatric disorder. The rise of benzodiazepine prescriptions is very worrying amid the COVID-19 pandemic. 
In general, there is no denying the fact that we see more deaths related to overdose, addiction problems, suicides in the world (NIDA, 2020; National Institute of Mental Health, 2020).

Due to the COVID-19 pandemic, a mental health crisis is expected and we will probably see an even greater increase in anxiety and insomnia. In the last 12 months, anxiety has been recorded in more than half of $65 \%$ and $48 \%$ of insomnia in our research. The findings coincide with the research done by the American Psychiatric Association in March 2020. 48\% of the general population reported anxiety, $36 \%$ informed that the pandemic seriously affected their mental health and 19\% reported insomnia (New Poll, 2020). A systematic examination and meta-analysis performed by Pappa et al. (2020), thirteen studies were included in the analysis with a combined total of 33,062 participants, anxiety was assessed in 12 studies, with a pooled prevalence of $23 \cdot 2 \%$ and depression in 10 studies, with a prevalence rate of $22 \cdot 8 \%$.

In a study by Lai et al. (2020), in China, a crosssectional study of 1257 respondents, it was found a high prevalence of mental health symptoms in healthcare professionals treating COVID-19 patients, overall, 50.4\%, $44.6 \%, 34.0 \%$, and $71.5 \%$ of all participants reported symptoms of depression, anxiety, insomnia, and anxiety, respectively. This increase in anxiety, insomnia and depression is alarming in both, the general population and health professionals. Benzodiazepines may be tempting at this time because of their "quick fix", but we know that because of this "quick fix", patients are unable to develop coping skills that can cope with stressors (Davydow et al., 2008; Gelpin et al., 1996; Guina and Merrill, 2018; Mellman et al., 1998). Patients become addicted to drugs and so long-term use becomes a problem of addiction. The first line of treatment for anxiety and insomnia is psychotherapy, so it should be used before switching to pharmacotherapy. There are several types of psychotherapy available, such as: Cognitive Behavioral Therapy for Anxiety, Insomnia, Supportive Therapy, Interpersonal Therapy, Trauma Focused Therapy, etc. Therapy can help develop rational thinking and help patients cope with their experiences and worries, and can help with anxiety and insomnia. Building a positive attitude with psychotherapy can take a long time and help develop the resilience to deal with all the stressful factors in life. Elasticity is a trait that shows how adaptable an individual is to stressful events. People with high elasticity can adapt and have a low risk of anxiety, insomnia and stress. Given that people with low elasticity are at high risk of insomnia and anxiety during stressful events such as the current pandemic. Low elasticity may increase anxiety and insomnia in some people with the current pandemic.

Prescription of benzodiazepines has increased dramatically over the past decade and during the COVID19 pandemic. Overall in our research, the use of benzodiazepines shows an increase rate of $20.9 \%$. Most respondents use benzodiazepines because of anxiety, insomnia, restlessness and $47 \%$ said that the drug helps a lot (on a scale of 8 to 10 ).

\section{Conclusion}

This epidemic leads to additional health problems such as: stress, anxiety, depressive symptoms, insomnia, denial, anger and fear, globally. Collective problems affect the day-to-day behavior, cost-effectiveness, prevention and decision-making strategies of policy makers, health organizations and medical centers, which can weaken COVID-19 control strategies and lead to greater morbidity and global mental health needs.

The focus is on the transmission of COVID-19 infection worldwide, while distracting the public from the psychosocial consequences of the affected individuals and the general population. New mental health issues related to this global event, COVID-19 infection, can escalate into long-term health problems, isolation and stigma. Global health measures should be applied to psychosocial stressors, especially related to the use of isolation/quarantine, fear and vulnerability among the general population. Inclusive response around the world should include a focus on the impact on the mental health of patients and the general population.

\section{References}

Agrawal, R., 2020. Careful prescribing of benzodiazepines during COVID-19 pandemic: A review, J Ment. Health Clin. Psychol. 4(4), 13-16. Available at: https://doi.org/10.29245/2578-29599/2020/4.1214.

Agarwal, D.S., Landon, E.B., 2019. Patterns in outpatient benzodiazepine prescribing in the United States. JAMA Netw. Open 2(1), e187399. Available at: https://www.doi.org/10.1001/jamanetworkopen.2018.7399

Agrawal, R., Verma, S., Halappanavar, M., 2020. Measuring the effectiveness of benzodiazepine prescriptions control in community setting using prescription drug monitoring program (PDMP). Community Mental Health Journal 2020. Available at: https://doi.org/10.1007/s10597-02000686-5.

Baldessarini, J.R., 2019. Epidemiology of suicide: recent developments. Epidemiol. Psychiatr. Sci. 29, e71. Available at: https://doi.org/10.1017/S2045796019000672.

Brooks, M., 2020. COVID-19: Mental illness the 'inevitable' Next pandemic? Medscape. Available at: https://www.medscape.com/viewarticle/928756.

Centers for Disease Control and Prevention, 2020. Corona virus disease 2019 (COVID-19). Available at: https://www.cdc.gov/coronavirus/2019-ncov/index.html

Clopton, J., 2020. Tsunami of grief to hit as more loved ones die. WEBMD. Available at: https://www.webmd.com/lung/news/20200413/tsunamiof-grief-to-hit-as-more-loved-ones-die. 
Davis, N., 2020. Urgent studies needed into mental health impact of Coronavirus: effects of lockdown and of COVID-19 itself could be deep and long-terms, say researchers. The Guardian. Available at: https://www.theguardian.com/world/2020/apr/15/urgentstudies-needed-mental-health-coronavirus-lockdown.

Davydow, D.S., Gifford, M.J., Desai, V.S., Needham, M.D., Bienvenu, O.J., 2008. Posttraumatic stress disorder in general intensive care unit survivors: a systematic review. Gen. Hosp. Psychiatry 30(5), 421-434. Available at: https://doi.org/10.1016/j.genhosppsych.2008.05.006.

Gelpin, E., Bonne, O., Peri, T., Brandes, D., Shalev, A.Y., 1996. Treatment of recent trauma survivors with benzodiazepines: a prospective study. J. Clin. Psychiatry 57(9), 390-394.

Grasselli, G., Pesenti, A., Cecconi, M., 2020. Critical care utilization for the COVID-19 outbreak in Lombardy, Italy: early experience and forecast during an emergency response. JAMA 323(16), 1545-1546. Available at: https://doi.org/10.1001/jama.2020.4031.

Guina, J., Merrill, B., 2018. Benzodiazepines I: upping the care on downers: the evidence of risks, benefits and alternatives. J. Clin. Med. 7(2), 17. Available at: https://doi.org/10.3390/jcm7020017.

Hackethal, V., 2020. COVID-19 pandemic spells trouble for children's health. Medscape. Available at: https://www.medscape.com/viewarticle/928721.

Hedegaard, H., Minino, A.M., Warner, M., 2020. Drug overdose deaths in the United States, 1999-2018. NCHS Data Brief 356. Available at: https://www.cdc.gov/nchs/data/databriefs/db356-h.pdf. Last accessed: October 2, 2020.

Kalmbach, A.D., Anderson, R.J., Drake, L.C., 2018. The impact of stress on sleep: Pathogenic sleep reactivity as a vulnerability to insomnia and circadian disorders. J. Sleep Res. 27(6), e12710. Available at: https://doi.org/10.1111/jsr.12710.

Lai, J., Ma, S., Wang, Y., Cai, Z., Hu, J., Wei, N., Wu, J., Du, H., Chen, T., Li, R., Tan, H., Kang, L., Yao, L., Huang, M., Wang, H., Wang, G., Liu Z., Hu, S., 2020. Factors associated with mental health outcomes among health care workers exposed to corona virus disease 2019. JAMA Netw. Open 3(3), e203976. Available at: https://doi.org/10.1001/jamanetworkopen.2020.3976.

Mellman, T.A., Byers, P.M., Augenstein, J.S., 1998. Pilot evaluation of hypnotic medication during acute traumatic stress response. J. Trauma Stress 11(3), 563-569. Available at: https://doi.org/10.1023/A:1024460814230.

National Institute of Mental Health (NIMH), 2020. Suicide. Available at: https://www.nimh.nih.gov/health/statistics/suicide.shtml. Last accessed: October 4, 2020.

National Institute on Drug Abuse (NIDA), 2020. Overdose death rates. Available at: https://www.drugabuse.gov/drug- topics/trends-statistics/overdose-death-rates. Last accessed: October 2, 2020.

New Poll, 2020. COVID-19 impacting mental well-being: Americans feeling anxious, especially, for loved ones; Older adults are less anxious. Available at: https://www.psychiatry.org/newsroom/news-releases/newpoll-covid-19-impacting-mental-well-being-americansfeeling-anxious-especially-for-loved-ones-older-adults-areless-anxious. Accessed October 4, 2020.

Palagini, L., Moretto, U., Novi, M., Masci, I., Caruso, D., Drake, L.C., Riemann, D., 2018. Lack of resilience is related to stress-related sleep reactivity, hyperarousal, and emotion dysregulation in insomnia disorder. J. Clin. Sleep Med. 14(5), 759-766. Available at: https://doi.org/10.5664/jcsm.7100.

Pappa, S., Ntella, V., Giannakas, T., Giannakoulis, G., Papoutsi, E., Katsaounou, P., 2020. Prevalence of depression, anxiety, and insomnia among healthcare workers during the COVID-19 pandemic: A systematic review and metaanalysis. Brain Behave Immun. 88, 901-907. Available at: https://doi.org/10.1016/j.bbi.2020.05.026.

Srinivasa, M.R., 2020. COVID-19 pandemic and emotional health: Social psychiatry perspective. Indian J. Soc. Psychiatry 36(5), 24-42.

Sunita, N., 2020, COVID-19: What will be the new normal?. Down to Earth. Available at: https://www.downtoearth.org.in/blog/lifestyle/covid-19what-will-be-the-new-normal-70458.

Torales, J., O’Higgins, M., Castaldelli-Maia, J.M., Ventriglio, A., 2020. The outbreak of COVID-19 coronavirus and its impact on global mental health. International Journal of Social Psychiatry 66(4), 317-320. Available at: https://doi.org/10.1177/0020764020915212.

Vijayakumar, L., Thara, R., 2020. Because the mind matters. The Hindu. Available at:

https://www.thehindu.com/news/cities/chennai/becausethe-mind-matters/article31112798.ece.

Wolf, J.M., Nicholls, E., Chen, E., 2008. Chronic stress, salivary cortisol, and alpha-amylase in children with asthma and healthy children. Biol. Psychol. 78(1), 20-28. Available at: https://doi.org/10.1016/j.biopsycho.2007.12.004.

Wu, Z., McGoogan, J.M., 2020. Characteristics of and important lessons from the coronavirus disease 2019 (COVID-19) outbreak in China: summary of a report of 72314 cases from the Chinese Center for Disease Control and Prevention. JAMA 323(13), 1239-1242. Available at: https://doi.org/10.1001/jama.2020.2648.

Yang, J., Zheng, Y., Gou, X., Pu, K., Chen, Z., Guo, Q.J., R., Wang, H., Wang, Y., Zhou Y., 2020. Prevalence of comorbidities in the novel Wuhan coronavirus (COVID-19) infection: a systematic review and meta-analysis. Int. J. Infect. Dis. 94, 91-95. Available at: https://doi.org/10.1016/j.ijid.2020.03.017 


\title{
Резиме
}

\section{Скрининг на употребата на бензодијазепини за време на КОВИД-19 пандемијата кај општата популација}

\author{
Виктор Исјановски ${ }^{1}$, Милијана Кацарска² \\ ${ }^{1}$ Психијатриска болниияа „Скопје”, ул. Скупи 20 бр. 56, 1000 Скопје, РС Македонија \\ ${ }^{2}$ ПЗУ „Вита Медика“, ул. Ванчо Китанов бр. 19, 2400 Стурмица, РС Македонија
}

Клучни зборови: коронавирус, КОВИД-19, ментално здравје, бензодијазепини

Бензодијазепините се пропишуваат за третман на анксиозност и несоница во последните неколку децении. Постои зголемена загриженост за безбедноста на бензодиазепините поради смртни случаи поврзани со предозирање, зависности и когнитивни несакани ефекти. КОВИД-19 пандемијата се очекува да предизвика криза во менталното здравје. Неколку студии покажаа зголемување на анксиозноста и несоницата. Пропишувањето на бензодијазепини може да се зголеми како резултат на зголемување на анксиозноста и несоницата. Пандемијата бара брза адаптација на конвенционалните медицински практики за да се задоволат еволутивните потреби на ваквите ранливи пациенти. КОВИД-19 пациентите бараат третман со психотропни лекови. Пандемијата води кон дополнителни здравствени проблеми како што се: стрес, вознемиреност, депресивни симптоми, несоница, негирање, лутина и страв на глобално ниво.

Пандемијата КОВИД-19 е предизвик за човештвото. Таа истовремено е здравствена и социјална криза. Животот, веројатно нема да биде ист откако ќе излеземе од пандемијата. Има промени на ниво на поединци, семејства, заедници, држави, нации, меѓународни односи и начинот на кој сите ќе се справиме со низа човечки и еколошки ситуации. Катастрофите секогаш се поврзани со зголемени стапки на емоционалното здравје, од вознемиреност, до посттрауматско стресно нарушување, Искуствата од минатото покажаа психосоцијалните интервенции, од грижа за себе, психолошка прва помош, советување, социјална поддршка и формална психијатриска нега можат да го минимизираат влијанието на емоционалното здравје од катастрофи. Овие активности можат да бидат иницирани од индивидуи и професионалци. 